\title{
OPTIMASI BIAYA DAN WAKTU JALUR ANGKUTAN KOTA (ANGKOT) MALANG DENGAN METODE ANT COLONY BERBASIS PERANGKAT ANDROID
}

\author{
Dian Aulia Fitri ${ }^{1}$, Erfan Rohadi ${ }^{2}$, Ekojono ${ }^{3}$ \\ ${ }^{1,2,3}$ Program Studi Teknik Informatika, Jurusan Teknologi Informasi, Politeknik NegeriMalang. \\ 1dianauliafitri@gmail.com, ${ }^{2}$ erfanr@polinema.ac.id, ${ }^{3}$ ekojono@polinema.ac.id
}

\begin{abstract}
Abstrak
Kota Malang memiliki beberapa sebutan seperti Kota Pendidikan dan Kota Wisata. Disebut sebagai Kota wisata karena terdapat peninggalan-peninggalan bersejarah yang masih terjaga sehingga banyak wisatawan dalam maupun Luar Negeri dan disebut sebagai Kota Pendidikan karena terdapat banyak perguruan tinggi aktif di Kota Malang dan beberapa diantaranya menduduki peringkat terbaik di Indonesia. Tidak sedikit wisatawan dan mahasiswa baru ingin berkeliling Kota Malang, bagi mereka yang baru pertama kali berkunjung ke Malang membutuhkan informasi tentang angkutan-angkutan apa saja yang harus dinaiki serta jalur mana yang akan dilewati. Pada penelitian ini dikembangkan sebuah aplikasi dengan menggunakan metode ant colony atau koloni semut, yaitu sebuah metode yang meniru perilaku semut dalam mencari sumber makanan dan kembali ke sarangnya dengan secara alami mampu menemukan rute terpendek. Semut yang melewati rute terpendek akan meninggalkan aroma pheromone yang lebih tajam dan aroma tersebut akan diikuti oleh semut-semut yang lain menuju makanan.Hasil dari penelitian ini adalah metode ant colony dapat diterapkan dalam aplikasi ini yaitu untuk mencari rute angkutan kota Malang dengan perhitungan pada waktu tempuh dan biaya yang harus dikeluarkan oleh penumpang. Hasil pendapat responden menunjukkan $80 \%$ menyatakan bermanfaat dan $80 \%$ menyatakan mudah digunakan.
\end{abstract}

Kata kunci : Kota Malang, angkutan kota Malang, perguruan tinggi Kota Malang, ant colony

\section{Pendahuluan}

\subsection{Latar Belakang}

Kota Malang merupakan salah satu kota tujuan wisata favorit di Jawa Timur karena terdapat peninggalan-peninggalan bersejarah yang masih terjaga sehingga banyak wisatawan dalam maupun Luar Negeri yang ingin mengetahuinya. Kota Malang memiliki beberapa sebutan seperti Kota Pendidikan dan Kota Wisata. Disebut sebagai Kota wisata karena terdapat peninggalan-peninggalan bersejarah yang masih terjaga sehingga banyak wisatawan dalam maupun Luar Negeri yang ingin mengetahuinya, dan disebut sebagai Kota Pendidikan karena terdapat banyak perguruan tinggi aktif di Kota Malang dan beberapa diantaranya menduduki peringkat terbaik di Indonesia. Tidak sedikit wisatawan dan mahasiswa baru ingin berkeliling Kota Malang tetapi mereka menginginkan biaya yang murah. Mereka yang baru pertama kali berkunjung ke Malang membutuhkan informasi tentang angkutanangkutan apa saja yang harus dinaiki serta jalur mana yang akan dilewati.

Metode yang digunakan adalah ant colony atau koloni semut, yaitu sebuah metode yang meniru perilaku semut dalam mencari sumber makanan dan kembali ke sarangnya dengan secara alami mampu menemukan rute terpendek. Semut yang melewati rute terpendek akan meninggalkan aroma pheromone yang lebih tajam dan aroma tersebut akan diikuti oleh semut-semut yang lain menuju makanan.

\subsection{Rumusan Masalah}

Berdasarkan latar belakang di atas, maka rumusan masalah yang didapat adalah:

1. Bagaimana mengembangkan sebuah aplikasi untuk mengetahui jalur angkutan kota Malang dengan optimasi biaya dan waktu berbasis android?

2. Bagaimana penerapan metode ant colony pada aplikasi yang akan dibangun?

\subsection{Batasan Masalah}

Untuk memperoleh hasil yang baik maka pembahasan hanya terbatas pada masalah berikut:

1 Jalur angkutan kota (angkot) yang dibangun dalam aplikasi hanya wilayah Kota Malang.

2 Aplikasi yang dibangun dijalankan pada platform android.

3 Lokasi pencarian jalur angkutan kota (angkot) merupakan lokasi wisata Kota Malang dan Perguruan Tinggi di Kota Malang. 
4 Waktu yang ditampilkan adalah waktu estimasi bukan waktu pada saat pencarian rute (real time).

\section{Landasan Teori}

\subsection{Kota Malang}

Kota Malang terletak pada ketinggian antara 429 meter di atas permukaan air laut, terletak $112,06^{\circ}-112,07^{\circ}$ Bujur Timur dan $7,06^{\circ}-8,02^{\circ}$ Lintang Selatan merupakan salah satu kota tujuan wisata favorit di Jawa Timur karena terdapat peninggalan-peninggalan bersejarah yang masih terjaga sehingga banyak wisatawan dalam maupun Luar Negeri yang ingin mengetahuinya. Kota Malang memiliki beberapa sebutan seperti Kota Pendidikan dan Kota Wisata. Disebut sebagai Kota wisata karena terdapat peninggalan-peninggalan bersejarah yang masih terjaga sehingga banyak wisatawan dalam maupun Luar Negeri yang ingin mengetahuinya, dan disebut sebagai Kota Pendidikan karena terdapat banyak perguruan tinggi aktif di Kota Malang dan beberapa diantaranya menduduki peringkat terbaik di Indonesia.

\subsection{Angkutan Kota Malang}

Saat ini di Kota Malang terdapat sekitar 25 angkutan umum yang beroperasi dengan 3 terminal utama yaitu terminal Landungsari, terminal Hamid Rusdi (eks Gadang), dan terminal Arjosari. Untuk saat ini tarif angkutan kota Malang sebesar Rp 2.000,00 bagi pelajar dan Rp 3.500,00 bagi umum.

\subsection{Ant Colony}

Ant Colony (Koloni Semut) merupakan algoritma yang sering digunakan untuk menyelesaikan masalah optimasi. Semut dapat mencari lintasan terpendek dari suatu sumber makanan menuju sarangnya, tanpa harus melihatnya secara langsung. Semut-semut mempunyai penyelesaian yang unik dan sangat maju, yaitu menggunakan jejak pheromone pada suatu jalur untuk berkomunikasi dan membangun solusi, semakin banyak jejak pheromone ditinggalkan, maka jalur tersebut akan diikuti oleh semut

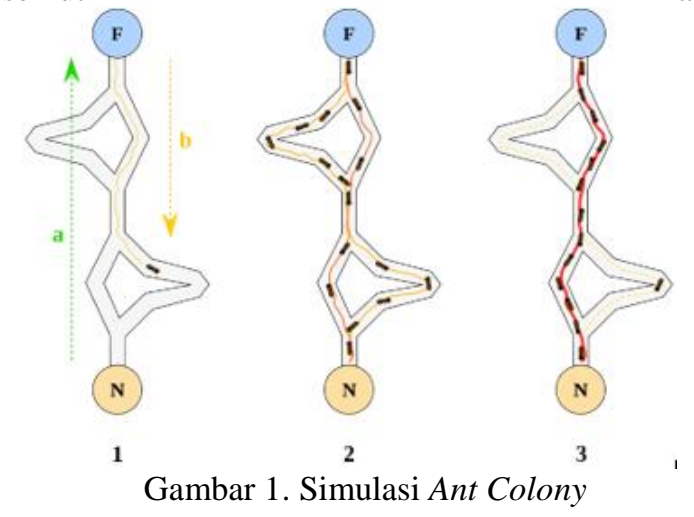

Langkah-langkah penyelesaian ant colony adalah sebagai berikut:

1. Langkah 1

a. Inisialisasi harga parameter-parameter algoritma. Parameter-parameter yang di inisialisasikan adalah:

1) Intensitas jejak semut antar kota dan perubahannya $\left(\tau_{\mathrm{ij}}\right)$

2) Banyak kota (n) termasuk $x$ dan $y$ (koordinat) atau dij (jarak antar kota)

3) Tetapan siklus-semut (Q)

4) Tetapan pengendali intensitas jejak semut $(\alpha)$

5) Tetapan pengendali visibilitas $(\beta)$

6) Visibilitas antar kota $=1 / \mathrm{d}_{\mathrm{ij}}\left(\eta_{\mathrm{ij}}\right)$

7) Banyak semut (m)

8) Tetapan penguapan jejak semut $(\rho)$

9) Jumlah siklus maksimum ( $\mathrm{NC}_{\max }$ bersifat tetap selama algoritma dijalankan, sedangkan $\tau_{\mathrm{ij}}$ akan selalu diperbaharui harganya pada setiap siklus algoritma mulai dari siklus pertama $(\mathrm{NC}=1)$ sampai tercapai jumlah siklus maksimum $\left(\mathrm{NC}=\mathrm{NC}_{\max }\right) \quad$ atau sampai terjadi konvergensi.

b. Inisialisasi kota pertama setiap semut

Setelah inisialisasi $\tau_{\mathrm{ij}}$ dilakukan, kemudian $\mathrm{m}$ semut ditempatkan pada kota pertama yang telah ditentukan.

2. Langkah 2

Pengisian kota pertama ke dalam tabu list. Hasil inisialisasi kota pertama semut pada langkah 1 harus diisikan sebagai elemen pertama tabu list. Hasil dari langkah ini adalah terisinya elemen pertama tabu list setiap semut dengan indeks kota pertama.

3. Langkah 3

Penyusunan rute kunjungan setiap semut ke setiap kota. Koloni semut yang sudah terdistribusi ke sejumlah atau setiap kota, akan mulai melakukan perjalanan dari kota pertama masing-masing sebagai kota asal dan salah satu kota-kota lainnya sebagai kota tujuan. Kemudian dari kota kedua masing masing, koloni semut akan melanjutkan perjalanan dengan memilih salah satu dari kota-kota yang tidak terdapat pada tabuk sebagai kota tujuan selanjutnya. Perjalanan koloni semut berlangsung terus menerus sampai semua kota satu persatu dikunjungi atau telah menempati tabuk. Jika s menyatakan indeks urutan kunjungan, kota asal dinyatakan sebagai tabuk(s) dan kota-kota lainnya dinyatakan sebagai $\{\mathrm{N}$-tabuk\}, maka untuk menentukan kota tujuan digunakan persamaan probabilitas kota untuk dikunjungi sebagai berikut: 


$$
\begin{aligned}
& P_{i j}^{k}=\frac{\left[\tau_{i j}\right]^{\alpha} \cdot\left[\eta_{i j}\right]^{\beta}}{\sum\left[\tau_{i k}\right]^{\alpha} \cdot\left[\eta_{i k}\right]^{\beta}} \text { untuk } j \in\left\{N-\text { tabu }_{k}\right\} \\
& \mathrm{k}^{\prime} \in\left\{\mathrm{N} \mathrm{tabu} \mathrm{u}_{k}\right\} \\
& \text { dan }
\end{aligned}
$$

$P_{i} j^{k}=0$, untuk $\mathrm{j}$ lainnya dengan $\mathrm{i}$ sebagai indeks kota asal dan $\mathrm{j}$ sebagai indeks kota tujuan.

4. Langkah 4:

a. Perhitungan panjang rute setiap semut.

Perhitungan panjang rute tertutup (length closed tour) atau $\mathrm{Lk}_{\mathrm{k}}$ setiap semut dilakukan setelah satu siklus diselesaikan oleh semua semut. Perhitungan dilakukan berdasarkan tabuk masing-masing dengan persamaan berikut:

$$
L_{k}=\sum_{s=1}^{n^{-1}} d_{\text {tabu }_{k}(s), \operatorname{tabu}_{k}(s+1)}
$$

Dengan $d_{i j}$ adalah jarak antara kota i ke kota $\mathrm{j}$ yang dihitung berdasarkan persamaan:

$$
d_{i j}=\sqrt{\left(x_{i}-x_{j}\right)^{2}+\left(y_{i}-y_{j}\right)^{2}}
$$

b. Pencarian rute terpendek

Setelah $\mathrm{Lk}_{\mathrm{k}}$ setiap semut dihitung, akan didapat harga minimal panjang rute tertutup setiap siklus atau LminNC dan harga minimal panjang rute tertutup secara keseluruhan adalah atau Lmin.

c. Perhitungan perubahan harga intensitas jejak kaki semut antar kota. Koloni semut akan meninggalkan jejak-jejak kaki pada lintasan antar kota yang dilaluinya. Adanya penguapan dan perbedaan jumlah semut yang lewat, menyebabkan kemungkinan terjadinya perubahan harga intensitas jejak kaki semut antar kota. Persamaan perubahan ini adalah:

$$
\Delta \tau_{i j}=\sum_{k=1}^{m} \Delta \tau_{i j}^{k}
$$

dengan $\mathrm{k}_{\mathrm{ij}}$ adalah perubahan harga intensitas jejak kaki semut antar kota setiap semut yang dihitung berdasarkan persamaan:

$\Delta \tau_{i j}^{k}=\frac{Q}{L_{k}} \quad$ untuk $(\mathrm{i}, \mathrm{j}) \epsilon$ kota asal dan kota

tujuan dalam $t a b u_{k}$.

$\Delta \tau_{i j}^{k}=0$ untuk (i,j) lainnya

5. Langkah 5:

a. Perhitungan harga intensitas jejak kaki semut antar kota untuk siklus selanjutnya. Harga intensitas jejak kaki semut antar kota pada semua lintasan antar kota ada kemungkinan berubah karena adanya penguapan dan perbedaan jumlah semut yang melewati. Untuk sik(as1)selanjutnya, sem(2.1) yang akan melewati lintasan tersebut harga intensitasnya telah berubah. Harga intensitas jejak kaki semut antarkota untuk siklus selanjutnya dihitung dengan persamaan:

$$
\tau_{i j}=\rho \cdot \tau_{i j}+\Delta \tau_{i j}
$$

b. Atur ulang harga perubahan intensitas jejak kaki semut antar kota. Intensitas jejak semut antar kota perlu diatur kembali agar memiliki nilai sama dengan nol.

6. Langkah 6:

Pengosongan tabu list, dan ulangi langkah 2 jika diperlukan. Tabu list perlu dikosongkan untuk diisi lagi dengan urutan kota yang baru pada siklus selanjutnya, jika jumlah siklus maksimum belum tercapai atau belum terjadi konvergensi. Algoritma diulang lagi dari langkah 2 dengan harga parameter intensitas jejak kaki semut antar kota yang sudah diperbaharui.

\section{Metodologi}

\subsection{Studi Literatur dan Pengumpulan Data}

Pada kegiatan ini penulis melakukan studi literatur yaitu mencari beberapa literatur yang berhubungan dengan android, codeIgniter, google maps API, dan ant colony. Pengumpulan data diperlukan untuk mencari data yang akan digunakan untuk penelitian berupa data jalur angkutan kota (angkot) Malang, dan data tempattempat wisata yang ada di Kota Malang.

\subsection{Analisis Kebutuhan Sistem dan Perancangan Sistem}

Dalam pengerjaan sistem "Optimasi Biaya dan Waktu Jalur Angkutan Kota (Angkot) Malang Berbasis Perangkat Mobile", dibutuhkan spesifikasi software dan hardware sebagai berikut:

1) Kebutuhan Software dan Hardware

a) Software

- Sistem Operasi Windows 7 / 8.1

- Android Studio

- Android SDK

- Java Development Kit (JDK)

b) Hardware

Untuk dapat melakukan perancangan dan menjalankan aplikasi, perlu memperhatikan kebutuhan perangkat keras yaitu Personal Computer (PC) atau notebook dengan spesifikasi sebagai berikut:

- Proccessor Intel Core i3

- RAM sebesar 4 GB

- VGA menggunakan NVidia Geforce GT$520 \mathrm{M}$

- Mouse dan Keyboard standar 
c) Smartphone

Sistem operasi Android minimal Jelly Bean

2) Perancangan Sistem

Pada kegiatan analisis proses dan perancangan sistem penulis melakukan 4 proses analisis yaitu, analisis data yang digunakan untuk penelitian berupa data jalur-jalur dari angkutan kota Malang, analisis Database yang sesuai dengan data yang ada, analisis interface, dan analisis sistem, keduanya mengacu pada WBS dan alur sistem yang dihasilkan dari proses perancangan sistem.

1. Implementasi

Tahap ini penulis melakukan implementasi hasil rancangan dengan melakukan pembuatan tampilan dan sistem menggunakan aplikasi Android Studio yang khusus untuk pembuatan aplikasi berbasis android dan menjalankan metode ant colony, sedangkan proses penyimpanan data menggunakan website dengan framework codeIgniter.

\section{Pengujian}

Tahap ini penulis melakukan 3 pengujian yaitu pengujian tampilan, Input/ Output, dan pengujian metode dari aplikasi. Dalam proses pengujian, hal yang terpenting adalah menguji metode ant colony dalam aplikasi pencarian rute angkutan kota (angkot) Malang berjalan atau tidak.

\section{Perancangan}

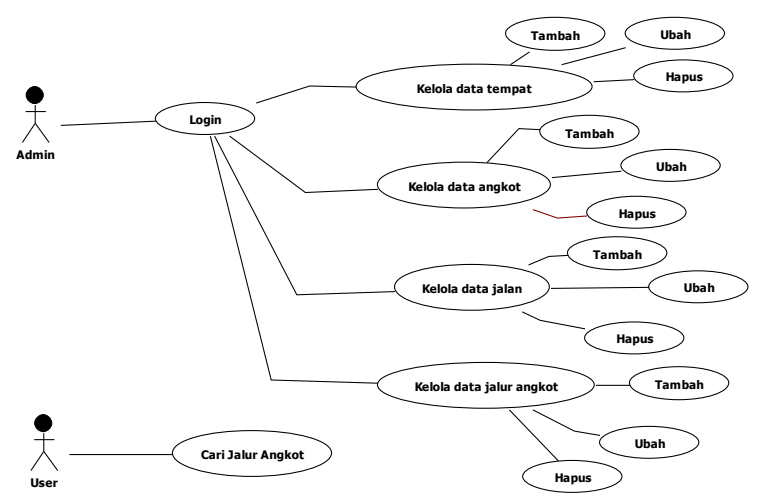

Gambar 2. Use Case Diagram

Di dalam use case dijelaskan terdapat dua aktor yaitu Admin dan User atau pengguna. Admin memiliki hak akses untuk mengelola halaman web yang berisi data-data tempat wisata dan perguruan tinggi, data jalan, data angkutan kota, dan jalur angkutan kota. Sedangkan user atau pengguna memiliki hak akses untuk mencari jalur angkutan kota melalui smartphone miliknya.

\section{Implementasi}

a. Halaman Login

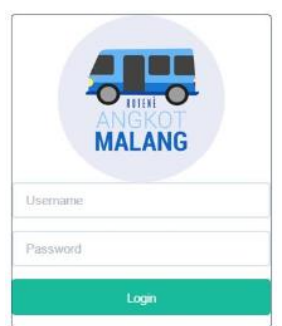

Gambar 3. Halaman Login

Admin memiliki hak penuh untuk mengelola website dari aplikasi "Optimasi Biaya dan Waktu Jalur Angkutan Kota (Angkot) Malang dengan Metode Ant Colony Berbasis Perangkat Android". Untuk membuka halaman tersebut, admin harus melakukan login terlebih dahulu dengan memasukkan username dan password dan akan dicocokkan dengan database yang telah ada. Apabila data yang dimasukkan sesuai, maka admin dapat memasuki halamannya, tetapi apabila data yang dimasukkan tidak sesuai dengan database maka admin tidak dapat mengakses halaman tersebut.

b. Halaman Data Tempat

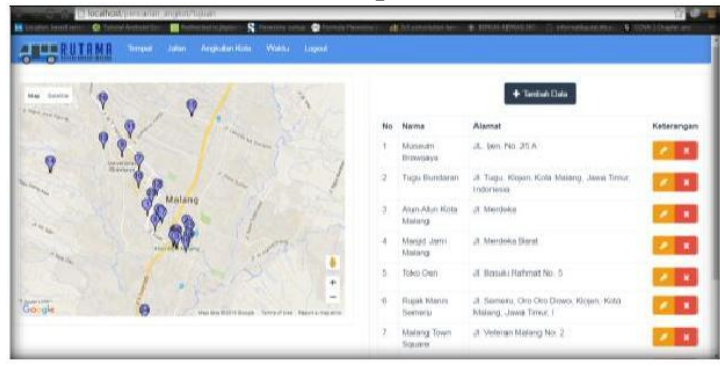

Gambar 4. Halaman Data Tempat

Tampilan dari halaman utama tempat berisikan data-data tempat wisata dan perguruan tinggi di Kota Malang yang tersimpan di database. Di bagian peta merupakan tanda tempat kunjungan yang telah ditentukan berdasarkan latitude dan logitude tempat masing-masing. Sedangkan di bagian tabel berisikan nomor, nama tempat wisata, serta alamat dari nama tempat tersebut. Di bagian atas tabel data tempat kunjungan terdapat tombol tambah data yang berguna untuk menambah data tempat wisata dan perguruan tinggi. Di tabel keterangan merupakan tombol yang berguna untuk mengubah data (warna kuning), dan untuk menghapus data dari database (warna merah).

c. Halaman Data Jalan

Tampilan dari halaman utama jalan berisikan data-data jalan yang tersimpan di database. Data jalan ini merupakan jalan-jalan yang dilalui oleh angkutan kota Malang. Di 
bagian peta merupakan tanda jalan yang telah ditentukan berdasarkan latitude dan logitude jalan masing-masing. Sedangkan di bagian tabel berisikan nomor, alamat, serta latitude dan logitude dari jalan tersebut. Di bagian atas tabel data jalan terdapat tombol tambah data yang berguna untuk menambah data jalan. Di tabel keterangan merupakan tombol yang berguna untuk mengubah data (warna kuning), dan untuk menghapus data dari database (warna merah).

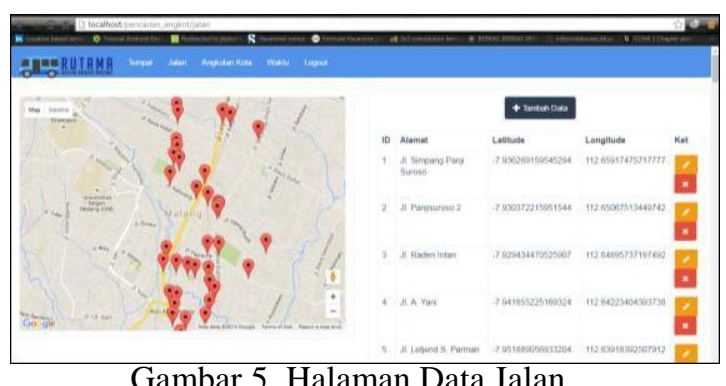

Gambar 5. Halaman Data Jalan

d. Halaman Angkutan Kota

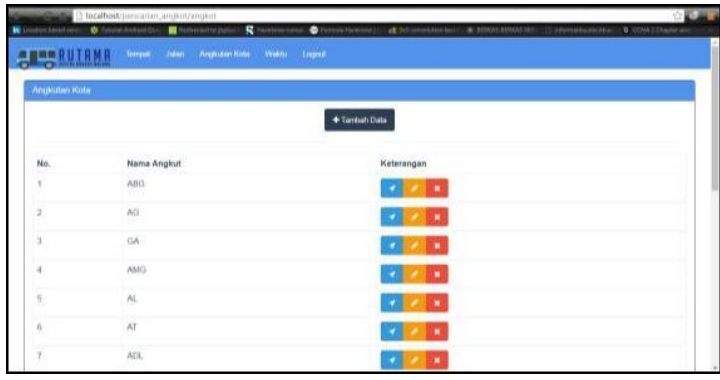

Gambar 6. Halaman Data Angkutan Kota

Tampilan dari halaman utama jalan berisikan data-data angkutan kota yang tersimpan di database. Data ini merupakan angkot-angkot yang ada di Kota Malang. Di bagian atas terdapat tombol tambah data yang berguna untuk menambah data angkutan kota. Di tabel keterangan merupakan tombol yang berguna untuk kelola jalur angkot (warna biru), mengubah data (warna kuning), dan untuk menghapus data dari database (warna merah).

e. Halaman Jalur Angkutan Kota

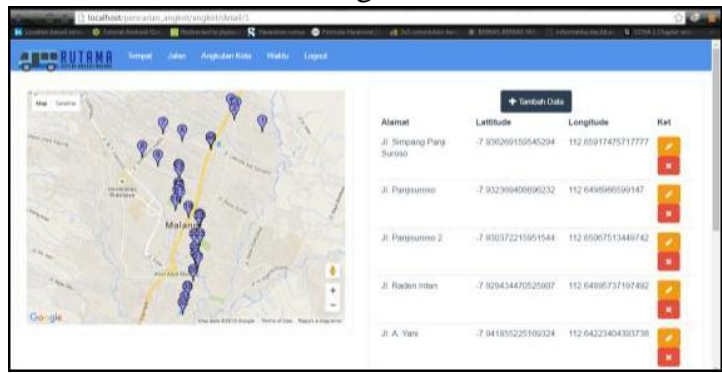

Gambar 7. Halaman Jalur Angkutan Kota
Untuk melihat jalur dari setiap angkutan kota admin harus menekan tombol detail (warna biru) pada halaman angkutan kota. Setelah menekan tombol tersebut, admin akan menuju halaman jalur angkutan kota yang berisikan nama-nama jalan.

f. Halaman Pencarian Jalur Angkutan Kota

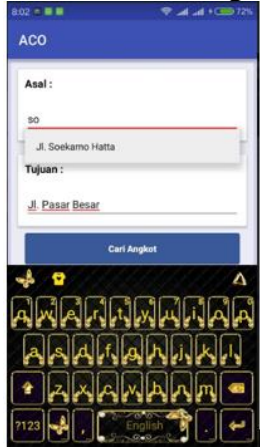

Gambar 8 Halaman Pencarian

User atau pengguna hanya dapat melakukan pencarian rute angkutan kota saja. Pencarian dilakukan melalui smartphone mereka. Untuk melakukan pencarian rute angkutan kota, mereka harus mengisi pilihan tujuan tempat dan awal tempat yang akan dicari angkutan kotanya.

\section{Pengujian dan Pembahasan \\ 6.1 Pengujian}

Dalam pengujian akan dijelaskan mengenai hasil dari pencarian jalur angkutan kota Malang dan hasil kuisioner dari responden untuk aplikasi.

a. Hasil Pencarian Jalur

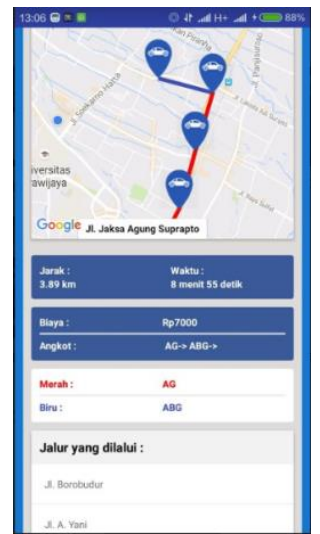

Gambar 9 Hasil Pencarian Jalur Angkot

Gambar tersebut menjelaskan mengenai hasil pencarian jalur angkutan kota yang telah dicari sesuai dengan metode ant colony yang telah diterapkan.

\section{b. Hasil Kuisioner}

Kuisioner digunakan untuk pengujian aplikasi. Responden yang menjawab kuisioner aplikasi pencarian jalur angkot sebanyak 20 responden dengan hasil seperti pada tabel 1 . 
Tabel 1. Hasil Kuisioner

\begin{tabular}{|c|c|c|c|c|}
\hline No & Pertanyaan & Kurang & Cukup & Baik \\
\hline 1 & $\begin{array}{l}\text { Pengetahuan } \\
\text { Anda tentang } \\
\text { jalur } \\
\text { angkutan kota } \\
\text { Malang }\end{array}$ & 7 & 12 & 1 \\
\hline 2 & $\begin{array}{l}\text { Manfaat } \\
\text { aplikasi } \\
\text { pencarian } \\
\text { jalur } \\
\text { angkutan kota } \\
\text { menurut } \\
\text { Anda }\end{array}$ & 2 & 2 & 16 \\
\hline 3 & $\begin{array}{l}\text { Tampilan } \\
\text { aplikasi } \\
\text { pencarian } \\
\text { jalur angkot } \\
\text { menurut } \\
\text { Anda }\end{array}$ & 2 & 4 & 14 \\
\hline 4 & $\begin{array}{l}\text { Tingkat } \\
\text { kemudahan } \\
\text { aplikasi } \\
\text { menurut } \\
\text { Anda }\end{array}$ & 1 & 3 & 16 \\
\hline
\end{tabular}

\subsection{Pembahasan}

Dalam pengujian metode telah dijelaskan hasil dari pencarian jalur angkutan kota dengan tujuan yang telah dicontohkan. Hasil dari pencarian tersebut berhasil dimunculkan dengan waktu yang ditempuh serta biaya yang dikeluarkan. Hal ini berarti metode Ant Colony berhasil dibangun dan dapat diterapkan dalam pencarian jalur angkutan kota Malang.

Sedangakan dalam tabel pengujian aplikasi dijelaskan bahwa respondennya sebanyak 20 dan terdiri dari mahasiswa baru, warga Malang, dan warga luar kota Malang. Berdasarkan hasil kuisioner, 16 responden atau $80 \%$ responden menyebutkan bahwa aplikasi pencarian jalur angkutan kota berguna.

\section{Kesimpulan dan Saran \\ 7.1 Kesimpulan}

Aplikasi pencarian rute angkutan kota Malang dengan metode ant colony dikembangkan sesuai dengan perancangan dan dapat digunakan untuk mencari jalur angkutan kota dengan keluaran berupa rute, waktu, dan biaya. Fitur-fitur yang terdapat dalam aplikasi ini yaitu untuk admin terdapat login, kelola data tempat kunjungan (tempat wisata dan perguruan tinggi), kelola data jalan-jalan yang dilalui angkutan kota Malang, kelola data angkutan kota Malang, dan kelola data jalur angkutan kota Malang. Sedangkan untuk user atau pengguna memiliki fitur untuk mencari jalur angkutan kota melalui smartphone.

Metode ant colony berhasil dibangun dan diterapkan dalam aplikasi pencarian rute angkutan kota Malang dengan hasil berupa nama angkutan kota, waktu yang ditempuh, serta biaya yang dikeluarkan. Berdasarkan hasil pengujian aplikasi, $80 \%$ responden atau sebanyak 16 dari 20 responden menyatakan bahwa aplikasi pencarian jalur angkutan kota ini berguna.

\subsection{Saran}

Untuk pengembangannya, diharapkan aplikasi pencarian jalur angkutan kota Malang dengan metode ant colony dapat ditambah fitur mengenai posisi user selama di perjalanan dalam angkutan kota. Fitur ini diharapkan akan lebih membantu user agar tidak terjadi kesalahan dalam turun dari angkutan kota.

\section{Daftar Pustaka:}

Asmoko, H., (2014): Teknik Ilustrasi Masalah Fishbone Diagrams, [Online] Tersedia:http://www.bppk.depkeu.go.id/bdpi mmagelang/images/unduh/teknik ilustrasi masalah.pdf [02 Desember 2015]

Daqiqil, I., (2011): Framework CodeIgniter Sebuah Panduan dan Best Practice, Pekanbaru

Safaat, N., (2015): Android: Pemrograman Aplikasi Mobile Smartphone dan Tablet PC Berbasis Android Revisi Kedua, Bandung, Informatika

Wijono, E., (2014): Jalur Angkutan Kota Malang Dan Kode Angkot Malang. 2011 [Online] Tersedia:

http://www.mobilku.org/2011/11/jalurangkutan-kota-malang-dan-kode.html [30 November 2015]

Kadir, A., (2003): Dasar Pemrograman Java 2: Edisi II, Yogyakarta, ANDI

Prahasta, E., (2014): Sistem Informasi Geografis: Konsep-Konsep Dasar (Perspektif Geodesi \& Geomatika) Edisi Revisi, Bandung, Informatika

Raharjo, B., (2011): Belajar Ototidak Membuat Database Menggunakan MySQL, Bandung, Informatika

Santosa, B., \& Willy, P., (2011): Metoda Heuristik Konsep dan Implementasi, Surabaya, Guna Wijaya

Susilo, B., et all., (2011): Implementasi Dan Analisa Kinerja Algoritma Ant System (AS) Dalam Penyelesaian Multiple Travelling Salesman Problem (MTSP), Seminar Nasional Aplikasi Teknologi Informasi 2011, pp. F48-F54

Tyas, Y. S., \& Prijodiprodjo, (2013): Aplikasi Pencarian Rute Terbaik dengan Metode Ant 
Volume 3, Edisi 1, November 2016

Colony Optimization ACO, IJCS, 7(1), pp. 56-63

Yuwono, B., et all., (2009): Implementasi Algoritma Koloni Semut pada Proses Pencarian Jalur Terpendek Jalan Protokol di Kota Yogyakarta, Seminar Nasional Informatika 2009, pp. A112-A 